\title{
Validity of microporous polysaccharide hemispheres as a hemostatic agent in hepatic injuries: an experimental study in rats ${ }^{1}$
}

\author{
Validade de hemosferas microporosas de polissacarídeos como agente hemostático \\ em ferimentos hepáticos: estudo experimental em ratos
}

\author{
Maria de Lourdes Pessole Biondo-Simões², Roberta Petrauskas ${ }^{3}$,André Gustavo Dobrowolski ${ }^{3}$, Giselle Godoy, Flávia \\ Kaiber $^{4}$, Sérgio Ossamu Ioshii ${ }^{5}$ \\ 1. Study performed at the Pontifícia Universidade Católica do Paraná (PUCPR). Brazil. \\ 2. PhD. Associate Professor, Experimental Surgery, Department of Surgery at Universidade Federal do Paraná (UFPR) and Research \\ Methods at PUCPR \\ 3. Student, Scholarship National Council for Scientific and Technological Development (CNPq). \\ 4. Student, Scientific Initiation Program - PUCPR. \\ 5. Associate Professor, Experimental Pathology, Departament of Patholohy (PUCPR and UFPR)
}

\begin{abstract}
Introduction: In the treatment of hepatic injuries, there is not always adequate and secure hemostasis. A hepatic biopsy is indispensable in the evolution of focal or diffuse liver cell disease, being necessary for candidates for liver transplant and post-transplant treatment. Many patients suffer blood clotting that increases the risk of bleeding. For this reason, it is necessary to seek for substances capable of bringing about hemostasis quickly and effectively. Purpose: The aim of this study was to recognize the validity of the use of microporous polysaccharide hemispheres (MPH) as a hemostatic agent for hepatic injuries. Methods: Thirty Wistar rats were used, split into three groups. Under anaesthetic, a laparoptomy was done and resulted in a standard liver injury that was treated in Group A with MPH, in Group B with n-butyl-2-cyanoacrylate and in Group $\mathrm{C}$ with fibrin adhesive. Immediate hemostasis, delayed bleeding and histological evolution were timed. Results: The MPH took on average six minutes to promote hemostasis and also resulted in re-bleeding, which required reapplication; the n-butyl-2-cyanoacrylate took twenty seconds and the fibrin adhesive took one minute. The cyanoacrylate resulted in more intense adherence. The three adhesives mainly showed a chronic inflammatory reaction. The injuries treated with cyanoacrylate showed a larger area of injury $(p=0,0164)$. The density of the collagen was similar in all groups. Conclusion: The MPH, despite achieving hemostasis, proved to be no more favorable than n-butyl-cyanoacrylate and the fibrin adhesive, the latter resulting in the lowest tissue reaction.
\end{abstract}

Key words: 1 . Adhesives. 2. hemostatic.3. liver.

\section{RESUMO}

Introdução: No tratamento de lesões hepáticas nem sempre se tem hemostasia adequada e segura. Biópsia hepática é indispensável na evolução de doença hepato-celular difusa ou focal sendo necessária para candidatos à transplante hepático e para acompanhamento pós-transplante. Muitos doentes apresentam coagulopatias que aumentam os riscos de sangramento. Daí a necessidade de se procurar substâncias capazes de promover a hemostasia de forma rápida e efetiva. Objetivo: O objetivo deste estudo foi reconhecer a validade do uso de hemosferas microporosas de polissacarídeos (MPH) como agente hemostático para lesões hepáticas. Métodos: Utilizaram-se 30 ratos Wistar distribuídos em três grupos. Sob anestesia, fez-se uma laparotomia e produziu-se um ferimento hepático padrão que foi tratado no grupo A com MPH, no grupo B, com n-butil-2-cianoacrilato e no grupo $\mathrm{C}$ com adesivo de fibrina. Cronometrou-se o tempo para a obtenção da hemostasia imediata, a existência de sangramento tardio e a evolução histológica. Resultados: O MPH levou, em média, seis minutos para promover a hemostasia e apresentou re-sangramento exigindo reaplicação, o n-butil-2-cianoacrlato, 20 segundos e o adesivo de fibrina, um minuto. O cianoacrilato promoveu aderências mais intensas. Os três adesivos determinaram principalmente reação inflamatória do tipo crônico. As feridas tratadas com cianoacrilato apresentaram maior área de lesão ( $p=0,0164)$. A densidade do colágeno foi semelhante entre os grupos. Conclusão: O MPH, embora tenha conseguido hemostasia, não se mostrou mais favorável do que o n-butil-2-cianoacrilato e o adesivo de fibrina sendo que este último promoveu a menor reação tecidual.

Descritores: 1. Adesivos. 2. Hemostáticos. 3. Fígado. 


\section{Introduction}

In the treatment of traumatic liver injuries there is not always sufficient and secure hemostasis. Hepatic biopsies are frequently necessary for candidates for liver transplant, in addition to biopsies for diagnosis. These situations created the need to seek for substances capable of brining about hemostasis in the injuries quickly, practically and effectively. With biopsies there is the risk of complications such as bleeding and biliary drainage to the peritoneum. Hemorrhages can be very important and appear as bruises or result in variable and intense bleeding. In patients with blood-clotting alterations, a common situation in carriers of hepatopathies, the risk of bleeding is high in relation to normal clotting $(\mathrm{p}<0,001)^{1}$. Terjung et al. reported a hemorrhage incidence of $1.6 \%$ following liver biopsy, and $2.7 \%$ of intra-peritoneal or intra-hepatic bleeding ${ }^{2}$. The use of an adhesive could be a helpful hemostatic tactic. The search for an ideal hemostatic adhesive that can be widely used in clinical practice lasts for several years and includes characteristics that must be brought together in a single substance. This should be safe, biodegradable, easily applied and easy to use, should bring about effective hemostasis $^{3}$ and a good joining of injured tissues ${ }^{4}$. This ideal adhesive must not alter the healing process, nor should it have side effects or carcinogenic agents ${ }^{4}$. Many hemostatic agents have been researched and different types and compositions of agents have been developed, among them fibrin adhesive ${ }^{5-12}$, cyanoacrylate ${ }^{11,13,14}$, gelatineresorcine $^{13,15,16}$ and oxidized cellulose ${ }^{17}$. Recently microporous polysaccharide hemispheres (MPH) arrived on the market, constituting spherical particles of controlled porosity obtained from bioinert vegetable polysaccharides and facilitates hemostasis through rapid absorption of the fluid in the blood, accelerating the aggregation of the plaques and clotting ${ }^{18,19}$. The aim of this study is to recognize the validity of the use of MPH as a hemostatic agent and compare it to fibrin adhesive and n-butyl-2-cyanoacrylate in liver injuries in rats.

\section{Methods}

The project was submitted to the Committee for Ethics in Research with Animals at the University (Pontifícia Universidade Católica do Paraná) and was approved (receiving 85), following the guidelines of the Brazilian College of Animal Research. Thirty Wistar rats were used (Rattus norvegicus albinus, Rodentia mammalia) from the viverium at the University, all males between 110 and 120 days old and weighing $346.57 \pm 23.18$ grams. Throughout the study they were kept in the infirmary at the viverium in polypropylene boxes especially for the species in groups of five. The light-dark cycle was twelve hours and the temperature was $20 \pm 2 .{ }^{\circ} \mathrm{C}$ and the humidity was that of the room. They were distributed at random into three groups of tem. In Group A the liver injuries were treated with MPH
(Medafor ${ }^{\circledR}$ ), in Group B with n-butyl-2-cyanoacrylate (Hystoacril ${ }^{\circledR}$ ) and Group C with fibrin adhesive (Tissucol ${ }^{\circledR}$ ). Under anaesthetic induced from an intra-muscular injection of $0.1 \mathrm{ml} / 100 \mathrm{~g}$ of weight of solution composed of a milliliter of ketamine (50mg) and a milliliter of xylazine (20mg), the trychotomy, anti-sepsis with polyvinyl pirrolydone iodine and a median laparoptomy of four centimeters of the xyfoide process were done. An injury was made to the left hepatic lobe with a \#15 scalpel blade, compromising the whole thickness of the lobe and with an extension of one centimeter. In the animals from Group A, MPH was pulverized onto the injury until complete hemostasis was achieved. In Group B and C, a drop of n-butyl-2-cyanoacrylate and fibrin adhesive were applied respectively. The Tissucol kit is composed of four solutions. During preparation, solution I and II are mixed to make the Tissucol solution and solution III and IV to make the thrombin solution. The kit has a double application device which mixes the Tissucol solution with the thrombin during application, which will constitute solidified fibrin adhesive. Following the application of the adhesives to the ensanguined areas of the liver, the time and effectiveness of the hemostatic effect were observed. After closing the abdominal cavity, the rats were given pain killers with Paracetamol (Acetaminophen) in a single 200 $\mathrm{mg} / \mathrm{kg}$ dose administered orally. On the seventh day after the operation, euthanasia was performed on the animals with a lethal dose of intra-peritoneal thionembutal. In the relaparoptomy the presence of bruises or liquid in the cavity and adherences was investigated. The left hepatic lobe was removed and set in formalin at $10 \%$ for later histologic study. The blades were manufactured by the Experimental Pathology Laboratory at the University using the conventional technique of paraffin embedding. Cuts of five micrometers of thickness were done, colored with a hematoxilin-eosin solution, picrosirius and hematoxylinphosphotungstic. In the anatomy-pathology analysis, the degree of inflammation was evaluated based on qualitative criteria of the presence of neutrophils and foreign body granuloma. By microscope with a computerized method, the total area of the injury and the amounts of collagen and fibrin in the scar were evaluated. The results were submitted to statistical comparison using the Mann-Whitney nonparametric test, comparing the adhesives two by two. The level of significance considered was 0.05 , corrected by Bonferroni for multiple comparisons (values of $\mathrm{p}<0.0167$ indicated statistical significance).

\section{Results}

The average time for hemostasis for MPH was six minutes, for n-butyl-2-cyanoacylate, twenty seconds and fibrin adhesive one minute. Re-bleeding was observed through the layer of MPH applied to the injury in all the rats in Group A and reapplication was required. One animal from Group A died and two rats from Group B died in the first day after the operation. In none of the necropsies was flowing 
blood found in the cavity. During the relaparotomy, no blood or flowing liquid was found in the abdominal cavity in any rats from any of the three groups. In Groups A and B, adherence was observed in $100 \%$ of the rats and in Group C (fibrin adhesive) in $70 \%$ of the rats. The more intense adherences were found in Group B n-butyl-2-cyanoacylate, as more organs were involved than in the other two groups. The histological cuts in the livers revealed a chronic inflammatory reaction in $80 \%$ of the livers of the rats in Group $C$ and in $60 \%$ of those in Group A and B. In the others an acute-chronic process was found. The injuries treated with fibrin resulted in smaller wounds than those treated with cyanoacrylate $(\mathrm{p}=0.0164)$ and there was no significant difference in the wounds caused by MPH and cyanoacrylate $(p=0.2318)$ (Figure 1). The collagen was measured in order to evaluate the fibrosis in the scar, but no significant difference was observed between the groups for this variable. There was a significant difference between the groups concerning the amount of fibrin in the scar $(p=0.0056)$, which evaluates the degree of edema. Group A $(\mathrm{MPH})$ had the lowest amount of fibrin in the injury and Group B (n-butyl-2-cyanoacrylate) had the highest. For each of the variables, the null hypothesis that all the results would be the same was tested in the two types of adhesive under comparison, versus the hypothesis of alternative different results.

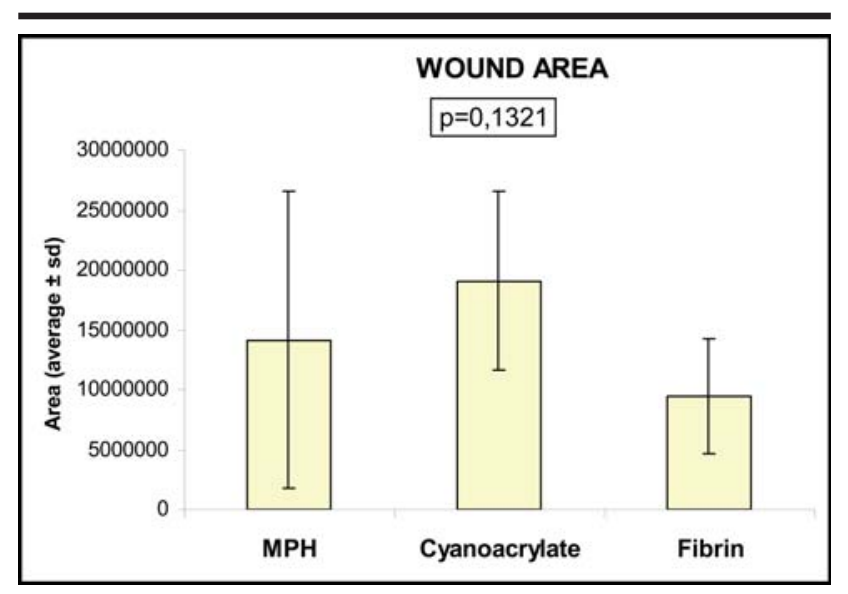

FIGURE 1 - Wound average promotes by MPH, cyanoacrylate and fibrin

MPH x cyanoacrylate $\mathrm{p}=0,2318$

$\mathrm{MPH} \times$ fibrin $\mathrm{p}=0,8148$

Cyanoacrylate $\mathrm{x}$ fibrina $\mathrm{p}=0,0164$

\section{Discussion}

Hepatic injuries caused by trauma are almost always complex injuries that are difficult to treat and treatments do not always result in secure hemostasis. The hepatic biopsy, in its turn, is increasingly practical both for diagnosis and for stabilizing patients who are awaiting a transplant or for the control of those who have already undergone a transplant. The biopsy may be done in the trans-cutaneous, trans-jugular procedure or by laparoscopic access. Many of these individuals suffer clotting caused by the disease itself or anti-clotting therapy. The hepatic biopsy has been seen to be secure, with a low incidence of bleeding. Terjung et al., reported $1.6 \%$ of patients submitted to the biopsy with bleeding and $2.7 \%$ with bruises ${ }^{2}$ and van der Poorten et al., $1 \%$. However, according to these authors, patients with clotting alterations showed a significant risk of bleeding $(\mathrm{p}<0.001)^{1}$. This can appear as bleeding in the peritoneum or in the form of bruises, including intra-parenchimatosis bleeding. These types of bleeding can be serious and require immediate surgical intervention as a life-saving measure, and cases of death under these circumstances are not uncommon. Another serious complication is biliary peritonitis. The possibility of using an adhesive that leads to hemostasis is an alternative. Several have been used. The most recognized are fibrin adhesive and n-butyl-2-cyanoacrylate. Fibrin adhesive is composed of highly purified, concentrated and pasteurized human fibrinogen, factor XIII and human trombin which are reconstituted in solutions with antifibrinolitic and agents and aprotinin, derived from bovine pulmonary tissue and potassium chloride solution, reproducing the final phases of clotting ${ }^{20}$. There have been many studies done with fibrin adhesive, experimental and clinical. Cohn et $\mathrm{al}^{5}$ caused serious hepatic injuries in heparinized pigs, who were treated with surgery. They reported that the use of fibrin sealing was useful for stopping the bleeding as it reduced the hypotension and coagulopathy in the animals on whom it was used. Falstrom et al ${ }^{6}$ used fibrin adhesive to treat hepatic injuries produced by biopsy with a needle in dogs that were anti-coagulated to simulate coagulopathies. The incidence of bleeding was lower in the groups that used the adhesive ( $p=0.0078)$. A similar study was carried out by Paulson et $\mathrm{al}^{7}$ who used a swine model on anti-coagulated animals with heparin and warfarin compared to animals with normal coagulation. They concluded that the fibrin adhesive was efficient $(\mathrm{p}<0.01)$ in the reduction of bleeding in hepatic biopsies. Davidson et $a l^{8}$ performed hepatectomies on pigs and compared the fibrin adhesive (Vivostat ${ }^{\circledR}$ ) with the oxidized cellulose sponge (Surgicel ${ }^{\circledR}$ ) and with controls that were not treated with the complementation of the hemostatic agent. They reported that both led to an immediate reduction in bleeding with less loss of volume $(\mathrm{p}<0.001)$. Albéniz Arbizu et $a l^{9}$ performed percutaneous hepatic biopsies on patients with clotting alterations and injected fibrin adhesive on the entire puncture and considered the procedure to be effective. Eder et $a l^{12}$ compared patients submitted to partial hepatectomy in which they applied fibrin adhesive on the hepatic injury with those on whom the adhesive was not applied. They observed a significant reduction in drainage of blood and bile, assessed after four and twenty-four hours. Pulsateri et $a l^{10}$ studied hepatic injuries on the swine model and used nine types of 
adhesives, which included microfibrilar collagen, oxidized cellulose, trombin, fibrinogen, polyglactin, aluminum sulfate, poli-N-acetyl and acetylated glucosamine. They concluded that the fibrogen and trombin hemostatic was the most efficient. Cyanoacrylate acts by polymerization on making contact with organic proteins, producing an exothermic reaction and forming a crust on the surface of the injury. It has bactericidal and bacteriostatic activity. Fontes et $a l^{11}$ performed an experimental study treating hepatic injuries and comparing the effectiveness of fibrin adhesive and cyanoacrylate. They reported that the time taken for hemostasis was similar, but that the injuries treated with fibrin showed signs of better regeneration and those treated with cyanoacrylate had a better reaction in terms of foreign body. Silveira et al ${ }^{13}$ compared the application of n-butyl-2-cyanoacrylate with gelatineresorcine-formaldehyde and observed that both were efficient in achieving hemostasis although the cyanoacrylate showed more significant cellular and tissue alterations. What was inconvenient about cyanoacrylate is that the bleeding accelerates rapid polymerization and solidification and he risk of adhering to the material and its overflow leads to the formation of firm adherence with other structures. Despite this, Fotiadis et al $^{14}$ treated hepatic injuries in dogs and considered the results to be efficient. The microporous polysaccharide hemispheres (MPH) constituted of polysaccharides extracted from purified vegetable starch which can activate the flow of coagulation concentrating plaques and coagulating proteins. They are spherical shaped particles of controlled porosity ${ }^{18,19}$. Murat et al ${ }^{19}$ utilized MPH and compared it to oxidized cellulose in partial nephrectomy of the lower pole, done in pigs. They reported a shorter time to achieve hemostasis $(p=0.004)$ which was effective and durable, with no foreign body residue after a week. According to Ereth et $a l^{21} \mathrm{MPH}$ proved to be a good hemostatic agent to be used in surgeries with high risk of infection since in an experimental study when they made injuries in rats and contaminated them with Escherichia coli and compared control with MPH and absorbable gel (Gelfoam $\left.{ }^{\circledR}\right)$ there was no increase in bacterial infection, which happened with Gelfoam ${ }^{\circledR}$. Tan and Tope ${ }^{18}$ utilized MPH in bandages, in dermatologic surgery, when drying skin neoplasies and compared them with electrocoagulation. They reported immediate rebleeding in $40.9 \%$ of the injuries treated with MPH and in $3.8 \%$ of those treated with electrocoagulation $(\mathrm{p}<0.05)$. When removing the bandage, there was no difference concerning the incidence of bleeding. According to Murat et $a^{19}$, MPH is bioinert, hypoallergenic and easy to apply. In this study, in the immediate experiment phase, MPH proved to be the least effective, taking the longest time to achieve complete hemostasis. Furthermore, as had already been reported by Tan and Tope ${ }^{18}$, re-bleeding was observed through he applied layer of MPH, which meant that reapplication was necessary to achieve hemostasis. In this study, both he fibrin adhesive and the cyanoacrylate proved effective in achieving rapid hemostasis. In terms of delay, all three agents were good as there was no register of delayed bleeding. The group that had adherence involving the highest number of organs was the cyanoacrylate group, a factor that has been referred to by many authors ${ }^{11,13,14}$. The inflammatory reaction in the wounds treated with n-butyl-2cyanoacrylate was more intense and showed signs of chronicity which were identified by the presence of giant foreign body cells. The fibrin adhesive was the one that involved the smallest area of the injury and no difference was seen concerning the density of the collagen. These data allow for the argument that the fibrin adhesive is the one with the best level of biocompatibility. This study shows the need for new experiments for a better definition of the role of MPH as a hemostatic agent as it was not shown to be effective in the control of bleeding in comparison to the other agents used in the study. Once hemostasis had been achieved, MPH proved to be a biocompatible agent, but further experiments are required to prove this claim.

\section{Conclusion}

Although MPH achieved hemostasis, it did not prove to be more favorable than n-butyl-2-cyanoacrylate and fibrin adhesive, with the latter having the lowest tissue reaction.

\section{References}

1. van der Poorten D, Kwok A, Lam T, Ridley L, Jones DB, Ngu MC, Lee AV. Twenty-year audit of percutaneous liver biopsy in a major Australian teaching hospital. Inter Med J. 2006; 36(11):692-9.

2. Terjung B, lemnitzer I, Dumoulin FL, Effenberger W, Brackmann HH, Sauerbruch T, Spengler V. Bleeding complications after percutaneous liver biopsy: an analysis of risk factors. Digestion. 2003; 67(3):138-45.

3. Mo X, Iwata H, Matsuda S,Ikada Y. Soft tissue adhesive composed of modified gelatin and polysaccharides. J Biomater Sci Polymer Edn, 2000; 11(4):341-51.

4. Thomazini-Santos IA, Barravieira SRCS, Mendes-iannini MJS, Barravieira B. Surgical adhesives. J Venom Anim Toxins. 2001; 7(2):159-71.

5. Cohn SM, CrossJH, Ivy ME, Feinstein AJ, Samotowka MA. Fibrin glue terminates massive bleeding after complex hepatic injury. J Trauma. 1998; 45(4):666-72.

6. Falstrom JK, Moore MM, Caldwell SH, Matsumoto AH, Abbott RD, Spotnitz WD. Use of fibrin sealant to reduce bleeding after needle liver biopsy in an anticoagulated canine model: work in progress. J Vasc Interv Radiol. 1999; 10(4):457-82. 
7. Paulson EK, Stephenson GR, Neal MC, Rossin V, Lawson JH. Use of fibrin sealant as a hemostatic agent after liver biopsy in swine. J Vasc Interv Radiol. 2000; 11(7):905-11.

8. Davidson BR, Burnett S, Javed MS, Seifalian A, Moore D, Doctor N. Experimental study of a novel fibrin sealant for achieving haemostasis following partial hepatectomy. Br J Surg. 2000; 87(6):790-5.

9. Albéniz-Arbizu E, López San Román A, Garcia González M, Foruny Olcina JR, Garcia-Hoz Rosales F, Bárcena Marugán R, Plaza Palácios G, Gil Grande LA. Fibrin glue sealed liver biopsy in patients with a liver transplantation or in liver transplantation waiting list: preliminary results. Transplant Proc. 2003; 35(5):1911-2.

10. Pusateri AE, Modrow HE, Harris RA, Holcomb JB, Hess JR, Mosebar RH, Reid TJ, Nelson JH, Goodwin CW, Fitzpatrick GM, McManus AT, Zolock DT, Sondeen JL, Cornum RL, Martinez RS. Advanced hemostatic dressing development program: animal model selection criteria and results of a study of nine hemostatic dressings in a model of severe large venous hemorrhage and hepatic injuri in swine. J Trauma. 2003; 55(3):518-26.

11. Fontes CER, Taha MO, Fagundes DJ, Ferreira MV, Prado Filho OR, Mardegan MJ. Estudo comparativo do uso de cola de fibrina e cianoacrilato em ferimento de fígado de rato. Acta Cir Bras. 2004;19(1):37-42.

12. Eder F, Meyer F, Nestler G, Halloue Z, Lippert H. Sealing of the hepatic resection area using fibrin glue reduces significant amount of postoperative drain fluid. World J Gastroenterol. 2005; 11(38):5984-7.

13. Silveira LMG, Matera A, Cortopassi SRG, Ferrigno CRA, Xavier JG, Cunha F. Comparação entre os efeitos da associação gelatina-resorcina-formaldeído e do n-butil2-cianoacrilato na síntese do parênquima hepático de coelhos. Braz J Vet Res Anim Sci. 2005; 42(4):284-90.
14. Fotiadis C, Leventis I, Adamis S, Gorgoulis V, Domeyer P, Zografos G, Sechas M, Skalkeas G. The use of isobutylcyanoacrilates as a tissue adhesive in abdominal surgery. Acta Chir Belg. 2005; 105(14):392-6.

15. Biondo-Simões MLP, Tenius FP, Cavazana WC, Adur RC, Santos ARL, Colaço LM. Uso de adesivo em trauma hepático: estudo experimental em ratos. Acta Cir Bras. 1993; 8(1):24-7.

16. Chapman WC, Clavien PA, Fung J, Khanna A, Bonham A. Effective control of hepatic bleeding with a novel collagen-based composite combined with autologous plasma. Arch Surg. 2000; 135(10):1200-4.

17. Davidson BR, Burnett S, Javed MS, Seifalian A, Moore D, Doctor N. Experimental study of a novel fibrin sealant for achieving haemostasis following partial hepatectomy. Br J Surg. 2000; 87(6):790-5.

18. Tan SR, Tope WD. Effectiveness of microporous polysaccharide hemispheres for achieving hemostasis in mohs micrographic surgery. Dermatol Surg. 2004; 30(6):908-14.

19. Murat FJ, Ereth MH, Dong Y, Piedra MP, Gettman MT. Evaluation of microporous polysaccharide hemospheres as a novel hemostatic agent in open partial nephrectomy: favorable experimental results in the porcine model. $\mathrm{J}$ Urol. 2004; 172(3):1119-22.

20. Chen RJ, Fang JF, Lin BC, Hsu YB, Kao JL, Kao YC, Chen MF. Selective application of laparoscopy and fibrin glue in the failure of nonoperative management of blunt hepatic trauma. J Trauma. 1998; 44(4):691-5.

21. Ereth M, Dong Y, Henderson N, Schrader L, Nuttal G, Dinenno D, Olsen L, Oliver W. Do microporous polysaccharide hemospheres (MPH) enhance surgical site infection in a rat model? Anesth Analg. 2004; 98(4 Suppl):SCA1-137.

\section{Correspondence:}

Maria de Lourdes Pessole Biondo-Simões

Rua Ari José Valle, 1987, Santa Felicidade

CEP 82030-000, Curitiba-Paraná - Brasil

Phone: (0XX41.3297.4359

e-mail:biondo@avalon.sul.com.br
Conflict of interest: none Financial source: none 